\title{
PENGARUH INTERAKSI EDUKATIF TERHADAP KONSEP DIRI SISWA DALAM BELAJAR
}

\author{
Yunisca Nurmalisa \\ Program Studi Pendidikan Pancasila dan Kewarganegaraan \\ Universitas Lampung Bandar Lampung \\ email: nurmalisayunisca@gmail.com
}

\begin{abstract}
This study aimed to explain the effect of educational interactions on students' self-concept in studying at YP Unila Bandar Lampung High School. The method used a quantitative approach with a descriptive design because the objectives and study were explained and described. Based on the existing analysis, it was found that $68 \%$ had an effect, this meant that educative interaction between students and teachers had an effect on self-concept, because if communication was built by teachers and students both students would not be reluctant or afraid to express their opinions to the teacher on the basis of self-concept good too. Meanwhile, it was also found that $72 \%$ of students had a good self-concept which meant the effect of changes that remained on their achievements would bring an attitude towards themselves. This also mean that the student's selfconcept could change if there are influences from other people who are trusted and that influence matches his will.
\end{abstract}

Keywords: educative interactions, communication, self-concept, learning, achievement

\begin{abstract}
Abstrak: Kajianini bertujuan untuk menjelaskan pengaruh interaksi edukatif terhadap konsep diri siswa dalam belajar. Metode yang digunakanyaitupendekatankuantitatifdengandesaindeskriptif karena sasaran dan kajiannya adalah menjelaskan dan mendeskripsikan.Berdasarkan analisis yangada, diperoleh $68 \%$ berpengaruh, ini berarti bahwa interaksi edukatif siswa dengan guru besar pengaruhnya terhadap konsep diri, karena jika komunikasi yang dibangun oleh guru dan siswa baik otomatis siswa tidak akan segan atau takut dalam mengungkapkan pendapat kepada guru dengan dasar konsep diri yang baik pula. Sementaraitu,didapati pula bahwa $72 \%$ siswa memiliki konsep diri yang baik yang artinyapengaruh perubahan-perubahan yang menetap pada prestasinya akan membawa sikap terhadap dirinya sendiri. Hal ini berarti konsep diri siswa itu pun dapat berubah jika ada pengaruh-pengaruh dari orang lain yang dipercaya dan pengaruh itu cocok dengan kehendaknya.
\end{abstract}

Kata Kunci: Interaksiedukatif, Komuniasi, Konsepdiri, Belajar, Prestasi

Pendidikan menduduki posisi penting untuk menuju perkembangan dan kemajuan suatu bangsa. Tujuan pendidikan nasional akan dapat tercapai apabila ada tanggung jawab dari semua pihak. Baik murid, orang tua, guru, pemerintah, lembaga pendidikan (sekolah) serta masyarakat. Adanya interaksi edukatif yang baik diantara keluarga, sekolah, dan masyarakat juga akan membuat tujuan pendidikan nasional tercapai. Interaksi edukatif ini terbentuk dengan adanya proses kemitraan yang terjadi antara sekolah dan stakeholder.

Konsep diri terbentuk melalui proses belajar sejak masa pertumbuhan seseorang dari kecil hingga dewasa.Secara psikologis, konsep diri merupakan perasaan dan keyakinan seseorang akan kemampuan yang dimiliki dari kehidupan semenjak kecil yang ditanamkan oleh orang tua maupun dari sekolah serta dari pengalaman seharihari. Masalah-masalah yang dialami siswa sering kali dan bahkan hampir semua berasal dari dalam diri. Konsep diri yang sehat tidak hanya positif, tetapi merupakan gambaran tentang diri yang sesuai dengan kenyataan dirinya. Untuk membentuk siswa dengan memiliki konsep diri yang positif dalam belajar diperlukannya interaksi edukatif yang baik. Berdasarkan latar belakang masalahpenulis memaparkan hasil kajian tentang "Pengaruh Interaksi Edukatif terhadap Konsep 
Diri Siswa dalam Belajar di SMAYP Unila Bandar Lampung".

Istilah interaksi, pada umumnya adalah suatu hubungan umpan balik(feed-back) antara individu yang satu dengan individu yang lainnya yangterjadi pada lingkungan masyarakat atau selain lingkungan masyarakat.Interaksiedukatifmenurut Sadirman A.M (2000:11) adalahproses interaksi yang disengaja, sadar akan tujuan, yakni untuk mengantarkan anak didik ketingkat kedewasaannya. Kesimpulannya interaksi edukatif adalah suatu proses hubungan timbal balik (feed-back) yang sifatnya komunikatif antara gurudengan siswa yang berlangsung dalam ikatan tujuan pendidikan, dan bersifatedukatif, dilakukan dengan sengaja, direncanakan serta memiliki tujuantertentu.Dengan demikian dalam interaksi edukatif harus ada dua unsur utamayang harus hadir dalam situasi yang disengaja, yaitu antara guru dan siswa.

Menurut Karsidi dalam Nanang (2014: 111) "Pada umumnya, keluarga terdiri dari ayah, ibu dan anak di mana masing-masing anggota keluarga tersebut saling mempengaruhi, saling membutuhkan, semua mengembangkan hubungan intensif antar anggota keluarga. Pergaulan antara orang tua terhadap anak dan anak itu sendiri dengan anggota keluarga lainnya di dalam lingkungan keluarga". Sekolah sebagai lembaga pendidikan formal, terdiri dari pendidik dan anak didik. Menurut Karsidi dalam Nanang (2014:113) mengatakan bahwa "dalam lingkungan sekolah seorang individu dihadapkan pula pada pola orientasi kehidupan yang lebih luas, di mana perangkat-perangkat aktivitas tersebut tidak ia temui di dalam keluarga."

Konsep diri merupakan salah satu faktor yang dapat mempengaruhi seseorang untuk dapat menyesuaikan diri dengan lingkungan sekitarnya. Menurut Jacinta F. Rini (2012:1) konsep diri didefinisikan sebagai keyaknian, pandangan, penilaian seseorang terhadap dirinya. Dapat disimpulkan bahwa konsep diri adalah keyaknian, pandangan, penilaian seseorang terhadap dirinya yang menyangkut apa yang ia ketahui dan rasakan tentang perilakunya, isi pikiran dan perasaannya, serta bagaimana perilakunya tersebut berpengaruh terhadap orang lain.Makadariitu, kajianini bertujuan untuk menjelaskan pengaruh interaksi edukatif terhadap konsep diri siswa dalam belajar di SMA YP Unila Bandar Lampung.

\section{METODE}

Berdasarkan pendapat tersebut maka penggunaan metode deskriptif dengan menggunakan pendekatan kuantitatif sangat tepat dalam penelitian yang peneliti laksanakan, karena sasaran dan kajiannya adalah menjelaskan dan mendeskripsikan pengaruh interaksi edukatif terhadap konsep diri siswa dalam belajar di SMA YP Unila dan menggambarkan serta menganalisis masalah yang ada sesuai kenyataan berdasarkan data-data yang ada di lapangan.

Populasi dalam kajian ini adalahsiswa kelas $X$ SMA YP Unila Bandar Lampung yang berjumlah 245 siswa. Menurut Sangadji dan Sopiah (2010 : 186) "sampel adalah bagian dari jumlah dan karakteristik yang dimiliki oleh populasi". Menentukan besarnya sampel, peneliti berpedoman pada pendapat Suharsimi Arikunto (2006:134) yaitu untuk sekedar ancer-ancer, maka apabila subjeknya kurang dari 100, lebih baik diambil semua sehingga penelitian ini merupakan populasi. Selanjutnya bila subjeknya lebih besar dari 100 dapat diambil 10\%-12\% atau 20\%-25\% atau lebih, tergantung setidak-tidaknya dari: (a) kemampuan peneliti dilihat dari segi waktu, tenaga dan dana, (b) sempitnya luasnya wilayah pengamatan, dan (c) besar kecilnya risiko yang ditanggung oleh peneliti.

Jumlahpopulasisebanyak 245 siswa, sehinggakajianinimengambilsampel $10 \%$ yakni 25 siswa. Kajian inimenggunakan 2 (dua) variabel, yaitu variable bebas $(\mathrm{X})$ berupa pengaruh interaksi edukatif dan variable terikat (Y) konsep diri siswa dalam belajar. Interaksi edukatif adalah suatu proses hubungan timbal balik (feed-back) yang sifatnya komunikatif antara guru dengan siswa yang berlangsung dalam ikatan tujuan pendidikan, dan bersifat edukatif, dilakukan dengan sengaja, direncanakan serta memiliki tujuan tertentu. Konsep diri adalah keyaknian, pandangan, penilaian seseorang terhadap dirinya yang menyangkut apa yang ia ketahui dan rasakan tentang perilakunya, isi pikiran dan perasaannya, serta bagaimana perilakunya tersebut berpengaruh terhadap orang lain. Pengaruhi nteraksi edukatif merupakan suatu interaksi yang dilakukan untuk mencapai tujuan pendidikan Indikator dalam variable ini adalah: (a) keluarga, (b) sekolah, dan (c) masyarakat. Konsep diri siswa merupakan persepsi siswa mengenai dirinya sendiri. Indiktor dalam variableiniadalah:(a) keyakinan, (b) pandangan, dan (c) penilaian. 
Tabel 1. JabaranVariabel

\begin{tabular}{|c|c|c|}
\hline \multicolumn{2}{|c|}{ Variabel Indikator } & \multirow{2}{*}{$\begin{array}{l}\text { Butir Soal } \\
\text { Apakah di dalam keluarga } \\
\text { menerapkan komunikasi yang } \\
\text { edukatif dalam hal menunjang } \\
\text { pembelajaran? }\end{array}$} \\
\hline $\begin{array}{l}\text { Interaksi } \\
\text { edukatif }\end{array}$ & Keluarga & \\
\hline & Sekolah & $\begin{array}{l}\text { Menurut anda apakah perlu } \\
\text { adanya pembinaan krakter } \\
\text { untuk meningkatkan sikap } \\
\text { empati sosial siswa di sekolah } \\
\text { ini? }\end{array}$ \\
\hline & Masyarakat & $\begin{array}{l}\text { Apakah ketika anda berinteraksi } \\
\text { dalam masyarakat } \\
\text { mendapatkan timbal balik yang } \\
\text { dapat diterapkan dalam } \\
\text { pembelajaran? }\end{array}$ \\
\hline \multirow[t]{3}{*}{$\begin{array}{l}\text { Konsep } \\
\text { diri siswa }\end{array}$} & Keyakinan & $\begin{array}{l}\text { Apakah anda memiliki } \\
\text { kepercayaan mengenai keadaan } \\
\text { pada diri sendiri yang relatif sulit } \\
\text { berubah? }\end{array}$ \\
\hline & Pandangan & \\
\hline & Penilaian & \\
\hline
\end{tabular}

Menurut Suharsimi Arikunto (2006:178) "reliabilitas menunjuk pada satu pengertian bahwa suatu instrumen yang cukup dapat dipercaya untuk digunakan sebagai alat pengumpul data karena instrumen tersebut sudah baik". Uji reliabilitas angket dilakukan dengan langkah-langkah sebagai berikut: (a) menyebarkan angket kepada 10 orang di luar responden, (b) hasil uji coba dikelompokkan dalam belahan ganjil dan genap, (c) hasil item ganjil dan genap dikorelasikan dengan product moment, $r_{x y}=\frac{N \Sigma x y-(\Sigma x)(\Sigma y)}{\sqrt{\left\{N \Sigma x^{2}-(\Sigma x)^{2}\right\}\left\{N \Sigma y^{2}-(\Sigma y)^{2}\right\}}}$

Teknik analisis data yang digunakan adalah teknik analisis deskriptif yaitu dengan cara menangkap secara objektif temuan-temuan di lapangan yang dibantu dengan mempergunakan tabel distribusi frekuensi, diintepretasikan dengan kalimat-kalimat atau pertanyaan-pertanyaan yang mudah dipahami. Adapun mengolah dan menganalisis data dalam penelitian ini digunakan dengan rumus Chi kuadrat (Sudjana, 2005:280). Untuk menguji keeratan maka digunakan rumus kontigensi (Sudjana, 2005:282). Agar C diperoleh dapat dipakai untuk derajat asosiasi antara faktorfaktor diatas maka harga $\mathrm{C}$ dibandingkan koefisien maksimum. Uji pengaruh makin dekat harga $\mathrm{C}$ pada $\mathrm{C}$ maksimum maka makin besar derajat asosiasi antara variabel (Sudjana, 2005:282).

\section{HASIL DAN PEMBAHASAN}

\section{Pengaruh Interaksi Edukatif terhadap Konsep Pemahaman Diri Siswa dalam Belajar}

Interaksi edukatif adalah suatu hubungan timbal balik (feed-back) antara individu yang satu dengan individu yang lainnya yangterjadi pada lingkungan masyarakat atau selain lingkungan masyarakat.Proses hubungan timbal balik (feedback) yang sifatnya komunikatif antara guru dengan siswa yang berlangsung dalam ikatan tujuan pendidikan, dan bersifat edukatif, dilakukan dengan sengaja, direncanakan serta memiliki tujuan tertentu. Dengan demikian dalam interaksi edukatif harus ada dua unsur utama yang harus hadir dalam situasi yang disengaja, yaitu antara guru dan siswa.

Menurut Jacinta F. Rini (2012:1) konsep diri didefinisikan sebagaikeyaknian, pandangan, penilaian seseorang terhadap dirinya. Konsep diri merupakan suatu kepercayaan mengenai keadaan pada diri sendiri yang relatif sulit berubah. Konsep diri siswa itu pun dapat berubah jika ada pengaruh-pengaruh dari orang lain yang dipercaya dan pengaruh itu cocok dengan kehendaknya.Belajar dapat terjadi karena semua unsur yang ada sifat-sifat dalam anggota badan kita bekerja sama untuk mewujudkan sesuatu. Unsur hati berkeinginan untuk belajar kemudian diteruskan oleh unsur otak untuk berpikir dikerjakan bersama-sama oleh anggota tubuh lainnya, sehingga akan terwujud aktivitas belajar, konsep seperti ini yang bisa dikategorikan konsep diri dalam belajar.

Berdasarkan data penghitungan angket diperoleh hasil sebagaimana dijabarkan dalam tabel 2.

Tabel 2. Distribusi Frekuensi variabel interaksi edukatif

\begin{tabular}{|c|c|c|c|c|}
\hline No & Kelas & Frekue & rsent: & se Kategori \\
\hline 1 & $10-11$ & 2 & $8 \%$ & $\begin{array}{c}\text { Tidak } \\
\text { Berpengaruh }\end{array}$ \\
\hline 2 & $12-13$ & 6 & $24 \%$ & $\begin{array}{c}\text { Kurang } \\
\text { Berpengaruh }\end{array}$ \\
\hline 3 & $\begin{array}{l}14-15 \\
\text { Jumlah }\end{array}$ & $\begin{array}{l}17 \\
25\end{array}$ & $\begin{array}{c}68 \% \\
100 \%\end{array}$ & Berpengaruh \\
\hline
\end{tabular}

Sumber:data analisis primer

Berdasarkan tabel di atas dapat diketahui bahwa sebanyak 2 responden atau $8 \%$ ada pada 
kategori tidak berpengaruh bahwa lingkungan sekolah seorang individu tidak terlalu berpengaruh pada pola orientasi kehidupan yang lebih luas, kemudian sebanyak 6 responden atau 24\% ada pada kategori kurang berpenaruh, dimana responden menganggap proseshubungan timbal balik (feed-back) yang sifatnya komunikatif antara gurudengan siswa yang berlangsung kurang mempengaruhi dalam ikatan tujuan pendidikan, dan yang terakhir sebanyak 17 responden atau $68 \%$ ada pada kategori berpengaruh yang berarti responden menganggap bahwa pentingya proses interaksi edukatif antara guru dan peserta didik

Variabelkonsepdiri berdasarkan data hasil penghitungan angket diperoleh hasil sebagaimana dituangkan dalam tabel 3 .

Tabel 3. Distribusi Frekuensi variabel Konsep diri

\begin{tabular}{|c|c|c|c|c|}
\hline No & $\begin{array}{c}\text { Kelas } \\
\text { Interval }\end{array}$ & Frekuensi & Persentase & Kategori \\
\hline 1 & $9-10$ & 4 & $16 \%$ & $\begin{array}{c}\text { Kurang } \\
\text { Baik }\end{array}$ \\
\hline 2 & $11-12$ & 3 & $12 \%$ & $\begin{array}{c}\text { Cukup } \\
\text { Baik }\end{array}$ \\
\hline \multirow[t]{2}{*}{3} & $13-15$ & 18 & $72 \%$ & Baik \\
\hline & Jumlah & 25 & $100 \%$ & \\
\hline
\end{tabular}

Sumber:data analisis primer

Berdasarkan tabel di atas sebanyak 4 responden dengan persentase $16 \%$ ada pada kategori Kurang Baik yang berarti responden kurang memahami dirinya yang menyangkut apa yang ia ketahui dan rasakan tentang perilakunya, isi pikiran dan perasaannya, kemudian sebanyak 3 responden dengan persentase $12 \%$ ada pada kategori Cukup Baik dengan konsep diri yang mereka pahami serta bagaimana perilakunya tersebut berpengaruh terhadap orang lain, dan sebanyak 18 responden atau $72 \%$ ada pada kategori baik terhadap konsep diri siswa, yang berarti menurut responden pemahaman seseorang tentang cara bertindak menyikapi suatu kebiasaan-kebiasaan serta tanggung jawab yang sesuai dengan aturan norma yang berlaku dalam lingkungannya

Untuk mengetahui bagaimana pengaruh interaksi edukatif terhadap konsep diri siswa maka diperlukan rumus sebagai berikut:

$$
x^{2}=\sum_{i=j}^{B} \sum_{j=i}^{k} \frac{(O i j-E i j)^{2}}{E i j}
$$

Kemudian dilanjutkan dengan menggunakan data tersebut sebagai bahan perhitungan, dengan terlebih dahulu mengetahui banyaknya gejala yang diharapkan terjadi menggunakan spss sebagai Berdasarkan tabel terdapat 25 data yang semuanya diproses sehingga kevalidannya $100 \%$. Pada tabel di atas terdapat nilai Asymp. Sig. 0.001 d" 0,05 , maka dapat disimpulkan bahwa Ho ditolak dan Hi di terima yang artinya ada hubungan yang signifikan antara interaksi edukatif dengan konsep diri siswa.

Interaksi edukatif adalah suatu hubungan timbal balik (feed-back) antara individu yang satu dengan individu yang lainnya yangterjadi pada lingkungan masyarakat atau selain lingkungan masyarakat.Proses hubungan timbal balik (feedback) yang sifatnya komunikatif antara guru dengan siswa yang berlangsung dalam ikatan tujuan pendidikan, dan bersifat edukatif, dilakukan dengan sengaja, direncanakan serta memiliki tujuan tertentu. Dengan demikian dalam interaksi edukatif harus ada dua unsur utama yang harus hadir dalam situasi yang disengaja, yaitu antara guru dan siswa.Bedasarkan hasil yang diperoleh $68 \%$ ada pada kategori berpengaruh, ini berarti bahwa interaksi edukatif siswa dengan guru besar pengaruhnya terhadap konsep diri diri, karena jika komunikasi yang dibangun oleh guru dan siswa baik otomatis siswa tidak akan segan atau takut dalam mengungkapkan pendapat kepada guru dengan dasar konsep diri yang baik pula.

Menurut Jacinta F. Rini (2012:1) konsep diri didefinisikan sebagai keyaknian, pandangan, penilaian seseorang terhadap dirinya. Konsep diri merupakan suatu kepercayaan mengenai keadaan pada diri sendiri yang relatif sulit berubah. Konsep diri siswa itu pun dapat berubah jika ada pengaruhpengaruh dari orang lain yang dipercaya dan pengaruh itu cocok dengan kehendaknya.Belajar dapat terjadi karena semua unsur yang ada sifatsifat dalam anggota badan kita bekerja sama untuk mewujudkan sesuatu. Unsur hati berkeinginan untuk belajar kemudian diteruskan oleh unsur otak untuk berpikir dikerjakan bersama-sama oleh anggota tubuh lainnya, sehingga akan terwujud aktivitas belajar, konsep seperti ini yang bisa dikategorikan konsep diri dalam belajar.

Dengan demikian peningkatan kualitas siswa melalui pendidikan ini, selain bobot kurikulum, kualitas siswa, juga menyangkut kemampuan guru untuk membimbingnya.Berdasarkan hasil penelitian terdapat $72 \%$ siswa memiliki konsep diri 
yang baik yang artinyapengaruh perubahanperubahan yang menetap pada prestasinya akan membawa sikap terhadap dirinya sendiri. Hal ini berarti konsep diri siswa itu pun dapat berubah jika ada pengaruh-pengaruh dari orang lain yang dipercaya dan pengaruh itu cocok dengan kehendaknya.

\section{SIMPULAN}

1. Interaksi edukatif yang terjadi antara siswa dan guru akan mempengaruhi proses pembelajaran yang berdampak pada kualitas diri siswa. Interaksi yang terbuka pada siswa yang sejalan dengan proses pembelajaran akan membuat

\section{DAFTAR RUJUKAN}

Arikunto, Suharsimi. 2006. Prosedur PenelitianSuatu Pendekatan Praktik. Jakarta: Rineka Cipta.

Jacinta F. Rini. 2002. Konsep Diri.http://www.epsikologi.com. (07 April 2017) siswa berani mengutarakan pendapat namun tetap dibarengi dengan aturan yang tegas sehingga proses pembelajaran yang dilakukan akan mudah disesuaikan dengan kebutuhan siswa.

2. Konsep diri yang baik pada setiap siswa sebagai individu memiliki dasar mental meliputi dorongan ingin tahu, ingin menemukan hal-hal dan gejala kehidupan, dan ingin memilih kenyataan. Dengan demikian peningkatan kualitas siswa melalui pendidikan ini, selain bobot kurikulum, kualitas siswa, juga menyangkut kemampuan guru untuk membimbingnya.

Sadirman A.M. 2000. Interaksi Guru dan Anak Didik dalam Interaksi Edukatif. Jakarta: Rineka Cipta.

Sangadji dan Sopiah. 2010. Metodologi Penelitian. Yogyakarta: Andi 